\title{
MEASURING HUMAN FACTORS IN MAINTENANCE: A LITERATURE REVIEW
}

\author{
R.H. Peach ${ }^{1}$ \& J.K. Visser ${ }^{1 *}$
}

\section{ARTICLE INFO}

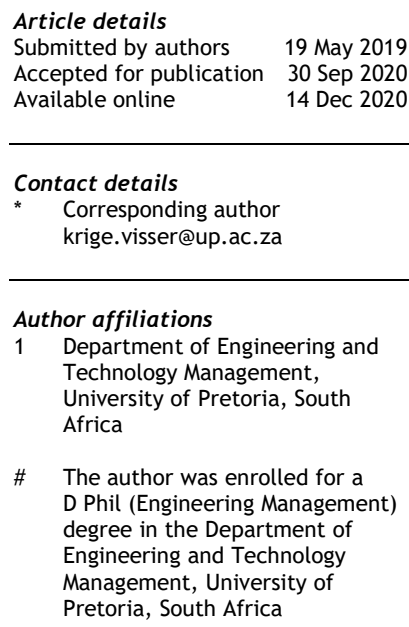

ORCID® identifiers

R.H. Peach

https://orcid.org/0000-0002-3104-4482

J.K. Visser

https://orcid.org/0000-0003-4334-9838

\section{DOI}

http://dx.doi.org/10.7166/31-4-2325

\section{ABSTRACT}

Strategies to manage the human factors in maintenance are documented in the maintenance management and human sciences spaces. However, it is unclear from the literature which indicators and measurements should be used for these factors. It is also unclear how to integrate them into traditional maintenance performance frameworks. This article summarises the maintenance human factors and measurements found in the literature. A systematic literature review of the most often cited human factors indicated a statistically significant correlation with the 'human factors analysis and classification system - maintenance extension' framework. A hierarchal maintenance measurement framework that includes these maintenance human factors is proposed.

\section{OPSOMMING}

Strategieë vir die bestuur van menslike faktore is goed gedokumenteer in die instandhouding vakgebied, sowel as in die menslike wetenskaplike gebied. Daar is egter baie onsekerheid oor watter indikatore en metings gebruik moet word in die beskikbare literatuur. Dit is ook onduidelik hoe om hierdie metings te integreer in die tradisionele instandhoudings prestasie-model. Hierdie artikel dien as 'n literatuuropsomming oor menslike faktore in instandhouding. 'n Sistematiese opsomming van die literatuur in terme van die instandhouding menslike faktore waarna daar die meeste in die literatuur na verwys word, toon dat daar 'n sterk statistiese korrelasie met die HFACS-ME raamwerk bestaan. As gevolgtrekking, word 'n hiërargiese instandhouding prestasie-model geïllustreer wat bogenoemde instandhouding menslike faktore inkorporeer.

\section{INTRODUCTION}

The effectiveness of maintenance functions is influenced by the overall human factors of the maintenance staff. The influence of human factors is increasingly acknowledged by technical and organisational specialists, who recognise that achieving greater operating reliability can be achieved by identifying and correcting repeating sources of failure that are within the organisation's control, and the system that contributed to the error [1, 2].

A maintenance function's effectiveness depends on the competency, training, and motivation of its staff [3]. This is validated by Simões, Gomes and Yasin [4], who state that future research needs to be aimed at determining human factor performance measurements for maintenance performance effort.

This literature review is based on the theoretical framework developed by Peach [5]. This framework links the relationship between maintenance human factors, maintenance performance, maintenance performance measurements, and maintenance resources, as illustrated in Figure 1. 


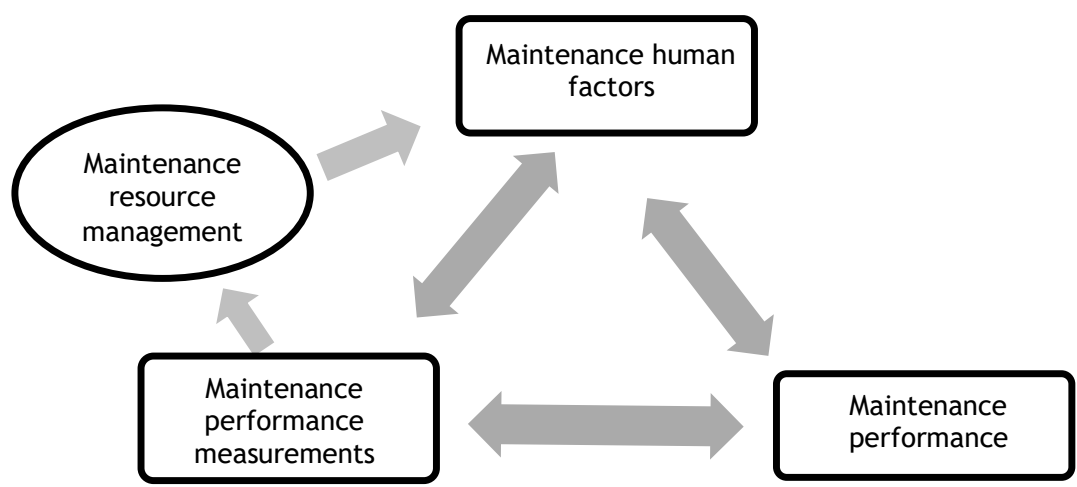

Figure 1: The relationship between maintenance human factors, maintenance performance measures, and maintenance performance

Maintenance performance measurements are used to determine whether the maintenance function's performance is satisfactory. This is done using quantitative values within a measurement framework. Through different psychological factors and theories, maintenance performance measurement influences maintenance human factors, which leads to either a positive or a negative influence on maintenance performance. Maintenance resource management therefore plays a critical role in managing the link between maintenance human factors and maintenance performance measurements. Maintenance resource management is also required to ensure that maintenance human factors are addressed, to influence the maintenance function's performance positively $[5,6]$.

The purpose of maintenance performance measurements is to manage the maintenance function's performance by tracking the important maintenance elements [7].

Maintenance human factors is a multi-disciplinary approach that focuses on human capabilities and limitations, with the human as the centre point of the system [8]. Meister [9] states that 'human factors' as a discipline is a descendant of psychology, as the first practitioners were experimental psychologists. He argues that the human factor discipline is unique in psychology (considered the 'mother'), as it has an effect on physical equipment. The same argument can be made for engineering (considered the 'stepfather'), as it accounts for the equipment and not the operator's behaviour. Human factors therefore span both the behavioural and physical domains.

A general critique of human factors is that long-term cost availability and ergonomic points of view in a wide range of industries need investigating. Sheikhalishahi [10] states that most studies focused on aviation, nuclear power plants, and chemical processing industries. He also comments that future research should focus on human resource management and allocation / scheduling [10, 11].

\section{MAINTENANCE HUMAN FACTOR MEASUREMENTS}

The goal of measuring maintenance human factors is to provide a leading indicator to predict future human performance, and to act on that prediction to improve on human performance [12-14]. Kantowitz [13] emphasises that measuring maintenance human factors provides the opportunity not only to determine the performance of an individual, but also the performance of teams, and hence of the department or overall system as well. He also advocates not only measuring human factors, but also discussion and action as a result.

Kantowitz [13] is critical that follow-up action on measurements is seldom done; that a single measure of a complex system is difficult to create (a statistical combination of multiple indicators is needed); that measurements are chosen on the basis of easy obtainability; that some measurements are chosen without the guidance of an adequate theory; and that human factors research needs to be highly generalisable.

Wang, Sun and Yang [15] developed a quantitative and objective method to analyse and evaluate human factors in aviation maintenance processes. This method is mathematically taxing and is not easily implementable at shop floor level.

Peach et al. [6] developed a maintenance performance framework that includes maintenance human factors, with training, competence, and motivation as the maintenance human factors to be measured. 
Maintenance human factors cannot be considered in isolation from human factors in other literature spheres. Several measurement criteria for human factors are found in the psychosomatic and medical literature, such as for stress, fatigue, and workload. Some measurements are either easily quantified using enterprise resource planning (ERP) systems, such as absenteeism, while others are difficult to obtain [16].

\subsection{Measurements of communication}

Roberts and O'Reilly [17] developed a 35-item questionnaire to measure 16 facets of organisational communication. Downs and Hazen [18] developed a communication satisfaction questionnaire (CSQ) measuring 10 factors. By using the CSQ, Clampitt and Downs [19] indicated that, for the two companies in their study, communication was perceived to have an above average impact on productivity. This CSQ has been used and adapted in several academic studies [20].

\subsection{Measurements of fatigue}

Chalder et al. [21] developed a rating scale to measure fatigue using 14 questions. Smets et al. [22] published a multidimensional fatigue inventory $(\mathrm{MFI})$ designed to measure fatigue in respect of general fatigue, physical fatigue, mental fatigue, reduced motivation, and reduced activity.

Horemans, Nollet, Beelen and Lankhorst [23] compared four measurement questionnaires of fatigue: the fatigue severity scale (FSS), the Nottingham health profile (NHP) energy category, the polio problem list (PPL) fatigue item, and the Dutch short fatigue questionnaire (SFQ).

\subsection{Measurements of workload}

De Waard [24] provides a simplified definition of workload as "a demand placed upon humans". O'Donnell and Eggemeier [25] provide a more complex definition: workload is "the portion of the operator's limited capacity required to perform a particular task". It can also be divided into physical workload and mental workload. Hwang et al. [26] give a generic definition of mental workload: "the amount of resource difference between task demands and capacity provision by an individual”.

Some measurements for workload have been summarised by Guhe et al. [27]. Hwang et al. [26] used the parasympathetic/sympathetic ratio (LF/HF), heart rate, heart rate variability (HRV), diastolic blood pressure, systolic blood pressure, eye blink frequency, and eye blink duration in their study to predict nuclear power plant operators' work performance.

Schulz, Kirschbaum, Prüßner and Hellhammer [28] investigated the correlation between cortisol responses after waking up and work overload, as an aspect of chronic stress. They observed a correlation between work overload and chronic fatigue, and between work overload and chronic exhaustion [28]. The human body releases hormones in response to stress. Severe stress can lead to high levels of cortisol, a metabolite of the primary stress hormone cortisone [33]. Measuring psychological stress through salivary cortisol levels as a biomarker is common practice in the medical and psychological fields.

De Winter [12] argues that (mental) workload is the most used human factor, and is easily measured through questionnaires. But he criticizes the explosive usage of the NASA task load index (NASA-TLX), as a measurement tool for workload, and compares the NASA-TLX, the Cooper Harper rating scale, and the subjective workload assessment technique (SWAT) questionnaires with each other.

\subsection{Measurements of stress}

In the Human performance reference manual of the Institute of Nuclear Power Operations [29], stress is defined as "the body's mental and physical response to a perceived threat in the environment". Active management of fatigue and stress can lead to fewer individual errors and better performance (Park et al., cited in [11]).

Cohen, Kamarck and Mermelstein [30], working in the sociological sphere, published a global measure of perceived stress, the perceived stress scale (PSS), which measures the points at which one's life situations are evaluated as stressful. The PSS consists of 14 questions.

Later works following the PSS include the perceived stress questionnaire, published in the psychosomatic sphere [31], and the Copenhagen psychosocial questionnaire (COPSOQ) [32]. The COPSOQ assesses psychosocial factors at work, stress, the well-being of employees, and some personality factors. 


\subsection{Measurements of distraction}

Distractions have been measured in office, aviation, and automotive environments using self-report and observational methods [34-39]. Noise levels measured in decibels (dB) can also affect the annoyance level of employees, and variable noise has a bigger influence than constant noise [40].

A failure to prevent distraction can also decrease work rate and increase errors. Studies on dual tasks (doing two or more tasks at once) have shown that performance decreases when working memory overlaps and conflicts with the attention processes of the task [41].

\subsection{Measurements of teamwork}

Generally, either self-report or observational methods are used to measure teamwork. Observational methods are normally costly, and limit the number of observations. Self-reporting of teamwork is still costeffective, easily distributed, effortless, and provides data to observe the characteristics of relationships in teamwork [42].

Valentine, Nembhard and Edmondson [42] cite behavioural processes and emergent states for teamwork, including communication, coordination, mutual respect, and psychological safety. Ruiz Ulloa and Adams [43] note that team effectiveness is a function of performance, attitude, and behaviour.

Valentine et al. [42] reviewed 35 surveys that measure teamwork, and found that most measure communication, coordination, and respect. The authors also tested the surveys for psychometric validity, as this builds confidence in the survey results.

\subsection{Summary}

From the sections above it can be seen that there are several human factor indicators, with several human factors measurements. Table 1 summarises some of the measurement techniques available in the literature to measure these maintenance human factors.

Table 1: Literature summary of human factor measurements

\begin{tabular}{|c|c|c|}
\hline Indicators & Measurement & Reference \\
\hline Stress & $\begin{array}{l}\text { The perceived stress scale (PSS) } \\
\text { Copenhagen psychosocial questionnaire (COPSOQ) } \\
\text { Dundee stress state questionnaire (DSSQ) } \\
\text { Stress diagnostic survey (SDS) } \\
\text { Salivary cortisol levels }\end{array}$ & $\begin{array}{l}\text { Cohen et al. [30] } \\
\text { Kristensen et al. [32] } \\
\text { Hellhammer et al. [44] } \\
\text { Langan-Fox et al. [45] }\end{array}$ \\
\hline Fatigue & $\begin{array}{l}\text { Multidimensional fatigue inventory (MFI) } \\
\text { Fatigue severity scale (FSS) } \\
\text { Nottingham health profile (NHP) } \\
\text { Polio problem list (PPL) } \\
\text { Dutch short fatigue questionnaire (SFQ). }\end{array}$ & Smets et al. [22] \\
\hline Workload & $\begin{array}{l}\text { NASA-TLX } \\
\text { Trier inventory for the assessment of chronic stress (TICS) } \\
\text { Instantaneous self-assessment (ISA) } \\
\text { Impact on mental workload (AIM) } \\
\text { Rating scale of mental effort (RSME) } \\
\text { Galvanic skin response } \\
\text { Parasympathetic/sympathetic ratio (LF/HF), heart rate, heart rate } \\
\text { variability (HRV), diastolic pressure, systolic pressure, eye blink } \\
\text { frequency, and eye blink duration } \\
\text { Cortisol responses after wakening }\end{array}$ & $\begin{array}{l}\text { Guhe et al. [27] } \\
\text { Hwang et al. [26] } \\
\text { Schulz et al. [28] } \\
\text { Langan-Fox et al. }\end{array}$ \\
\hline $\begin{array}{l}\text { Motivation / } \\
\text { morale }\end{array}$ & Absenteeism & Galar et al. [16] \\
\hline Communication & $\begin{array}{l}\text { Roberts and O'Reilly 35-item questionnaire } \\
\text { Communication satisfaction questionnaire (CSQ) }\end{array}$ & $\begin{array}{l}\text { Roberts and O'Reilly } \\
\text { [17] } \\
\text { Downs and Hazen [18] }\end{array}$ \\
\hline Teamwork & $\begin{array}{l}\text { Team effectiveness questions } \\
\text { NOTECHS (Non-technical skills evaluation system) }\end{array}$ & $\begin{array}{l}\text { Adams et al. [46] } \\
\text { Flin et al. [47] }\end{array}$ \\
\hline Distraction & $\begin{array}{l}\text { Noise levels } \\
\text { Peripheral displays }\end{array}$ & $\begin{array}{l}\text { Kjellberg et al. [40] } \\
\text { Somervell et al. [48] }\end{array}$ \\
\hline
\end{tabular}

However, it is both senseless and impractical to implement a system to measure all of these human factors that affect the maintenance worker and, therefore, the maintenance department's performance. It is 
unclear from the literature which specific performance indicators and measurements should be used to manage these factors.

The next section aims to determine the most often cited maintenance human factors in the literature, and to rank them according to the number of citations.

\section{SYSTEMATIC LITERATURE REVIEW TO DETERMINE THE MOST OFTEN CITED HUMAN FACTORS}

A meta-analysis using a systematic literature review was used to determine the most often cited maintenance human factors. WorldCat, the world's largest bibliographic database, was used for the systematic literature review [49]. A total of 39 peer-reviewed articles that listed human factors were included in the meta-analysis. The main search criterion for the systematic literature review was peerreviewed journal articles with the words 'human factor' and 'maintenance' or 'human factor' and 'measure' in the article title. It should also be applicable to the field of engineering or asset management. Figure 2 illustrates the information flow through the different phases of the systematic review and the different search criteria.

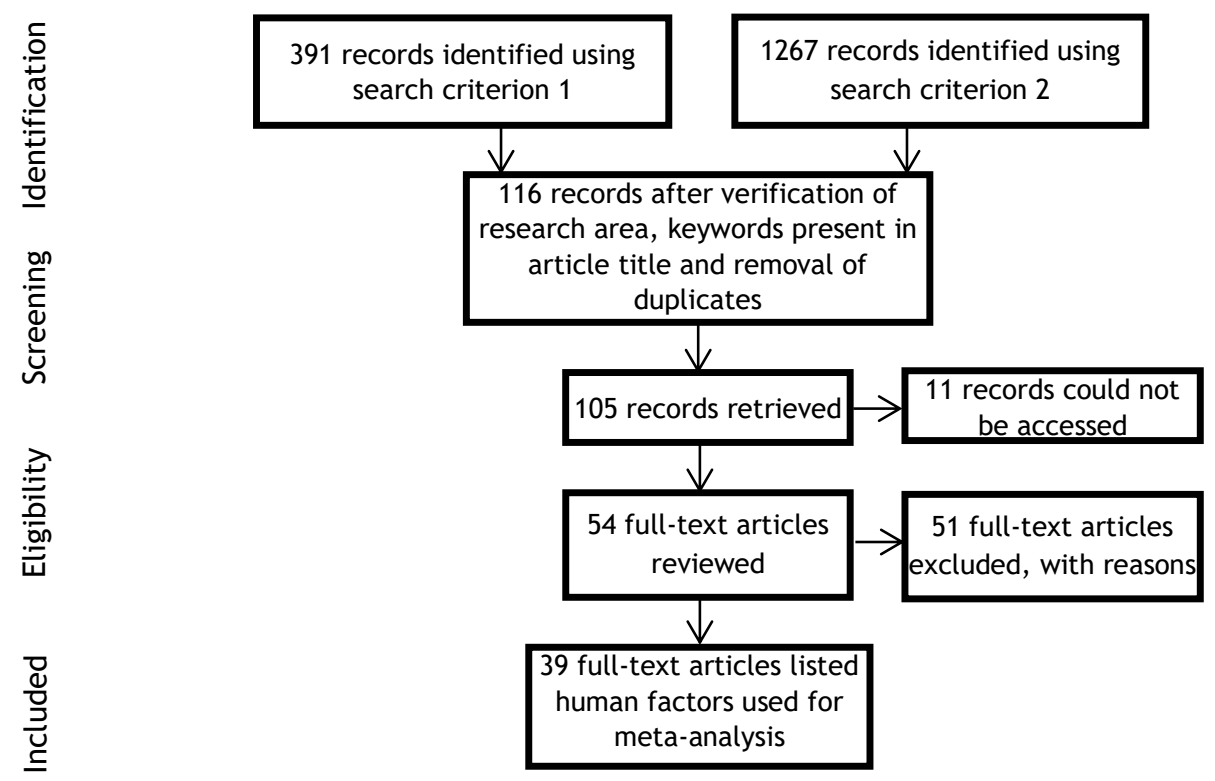

Figure 2: Information flow through the different phases of the systematic review (adapted from Liberati et al. [50])

Eleven of the 39 journal articles were published in the Proceedings of the Human Factors and Ergonomics Society Annual Meeting, and 15 related to aviation maintenance. The article that was most often cited was 'Selecting measures for human factors research' by Kantowitz [13], which was cited 102 times. The second most often cited article was 'Human factors in maintenance: Impact on aircraft mishap frequency and severity' by Krulak [51], followed by 'Human factors measurement for future air traffic control systems' by Langan-Fox, Sankey and Canty. [45]. The date range of the articles spans 1984 to 2019, and the authors with the most articles among the 39 articles were Sheikhalishahi, Pintelon and Azadeh [11].

\subsection{Results using minimal coding}

From the 39 full-text articles, 832 data points on human factors and 184 data points on human factor categories were gathered. Minimum coding (singular form versus multiple form of the same word) was used on the human factors to establish an unbiased view of the most often cited human factor. The most frequently cited human factors are shown in Table 2.

\subsection{PEAR model coding and grouping}

The Australian Civil Aviation Safety Authority (CASA) uses the PEAR model in their maintenance human factor training programme, Safety behaviours: Human factors for engineers. The aim of the training programme is to supplement existing human factor programmes for engineers and aviation maintenance organisations. It also serves as human factor training according to Australia's civil aviation safety 
regulations. The four focus points of the PEAR model are 'people', 'the environment', 'actions', and 'resources' [52, 53].

\subsubsection{Results using the PEAR model coding and grouping}

By using the PEAR model as a guideline, similar human factors were coded using the PEAR model terminology. In cases where no similar terminology was found in the PEAR model, and human factors were cited a number of times, the human factor was added to the PEAR model. In cases where the human factor was not frequently cited, it was not added to the adapted PEAR model. Human factors from the PEAR model that were not cited anywhere else in the literature were removed. Table 3 illustrates the adapted PEAR model used for the coding in this study. A cumulative percentage of 30 per cent was used to identify the top factors. The 16 most often cited factors using the PEAR model are shown in Table 4.

Table 2: Most frequently cited human factors using minimal coding

\begin{tabular}{|l|l|c|c|c|c|}
\hline Rank & Maintenance human factor & Frequency & Percentage & Cumulative frequency & Cumulative percentage \\
\hline 1 & Fatigue & 12 & $1.44 \%$ & 12 & $1.44 \%$ \\
\hline 2 & Illumination & 12 & $1.44 \%$ & 24 & $2.88 \%$ \\
\hline 3 & Communication & 11 & $1.32 \%$ & 35 & $4.21 \%$ \\
\hline 4 & Workload & 10 & $1.20 \%$ & 45 & $5.41 \%$ \\
\hline 5 & Cognitive dimensions & 8 & $0.96 \%$ & 53 & $6.37 \%$ \\
\hline 6 & Decision-making & 8 & $0.96 \%$ & 61 & $7.33 \%$ \\
\hline 7 & Noise level & 7 & $0.84 \%$ & 68 & $9.17 \%$ \\
\hline 8 & Time pressure & 7 & $0.84 \%$ & 75 & $9.74 \%$ \\
\hline 9 & Situation awareness & 6 & $0.72 \%$ & 81 & $10.34 \%$ \\
\hline 10 & Knowledge and experience & 5 & $0.60 \%$ & 86 & $10.94 \%$ \\
\hline 11 & Person factors & 5 & $0.60 \%$ & 91 & $11.54 \%$ \\
\hline 12 & Supervision & 5 & $0.60 \%$ & 96 & $12.14 \%$ \\
\hline 13 & Training & 5 & $0.60 \%$ & 101 & \\
\hline
\end{tabular}

Table 3: Adapted PEAR model with subcategories

\begin{tabular}{l|l|l|l|}
\multicolumn{1}{|c|}{ People } & \multicolumn{1}{|c|}{ Environment } & \multicolumn{1}{c|}{ Actions } & \multicolumn{1}{c|}{ Resources } \\
Physical factors & Physical & Skill requirements & Equipment, tools, and parts \\
Gender & Lighting & Certification requirements & Procedures/work cards \\
Age & Workspace & Inspection requirements & Training (resources) \\
Strength & Sound level & Information control requirements & Computers/software \\
Physiological factors & Weather & Technical manuals \\
Fatigue & Shift & & Materials \\
Psychological factors & Vibration & Other people \\
Workload (physical \& mental) & Heat & Paperwork/signoffs \\
Knowledge and skills & Reachability & & \\
Experience & Organisational & & \\
Stress & Communication & & \\
Training (psychological factors) & Supervision & & \\
Cognitive capabilities & Time \& time & & \\
Situation awareness & pressures & & \\
Motivation & Safety \& safety & & \\
Decision-making & culture & & \\
Attitude & Team \& team & & \\
Mental or emotional state & work & \\
Beliefs & Corporate culture & & \\
Psychosocial factors & Work pressure & & \\
Interpersonal skills/conflict & Crew structure & & \\
& Personnel & & \\
\hline
\end{tabular}

Table 4: Top 16 cited human factors using the PEAR model

\begin{tabular}{|c|c|c|c|c|c|}
\hline Rank & Maintenance human factor & Frequency & Percentage & $\begin{array}{l}\text { Cumulative } \\
\text { frequency }\end{array}$ & Cumulative percentage \\
\hline 1 & Communication & 23 & $2.77 \%$ & 23 & $2.77 \%$ \\
\hline 2 & Equipment, tools, and parts & 22 & $2.65 \%$ & 45 & $5.42 \%$ \\
\hline 3 & Procedures/work cards & 21 & $2.53 \%$ & 66 & $7.94 \%$ \\
\hline 4 & Knowledge and skills & 17 & $2.05 \%$ & 83 & $9.99 \%$ \\
\hline 5 & Experience & 17 & $2.05 \%$ & 100 & $12.03 \%$ \\
\hline 6 & Fatigue & 17 & $2.05 \%$ & 117 & $14.08 \%$ \\
\hline 7 & Training (resources) & 17 & $2.05 \%$ & 134 & $16.13 \%$ \\
\hline 8 & Workload (physical \& mental) & 17 & $2.05 \%$ & 151 & $18.17 \%$ \\
\hline 9 & Time \& time pressures & 15 & $1.81 \%$ & 166 & $19.98 \%$ \\
\hline 10 & Supervision & 15 & $1.81 \%$ & 181 & $21.78 \%$ \\
\hline 11 & Lighting & 14 & $1.68 \%$ & 195 & $23.47 \%$ \\
\hline 12 & Safety \& safety culture & 13 & $1.56 \%$ & 208 & $25.03 \%$ \\
\hline 13 & Workspace & 12 & $1.44 \%$ & 220 & $26.47 \%$ \\
\hline 14 & Stress & 12 & $1.44 \%$ & 232 & $27.92 \%$ \\
\hline 15 & Training (psychological factors) & 11 & $1.32 \%$ & 243 & $29.24 \%$ \\
\hline 16 & Cognitive capabilities & 10 & $1.20 \%$ & 253 & $30.45 \%$ \\
\hline
\end{tabular}




\subsection{HFACS-ME framework coding and grouping}

One of the best-known error investigation systems, the human factors analysis and classification system (HFACS), originated in aviation [54]. The framework is based on Reason's 'Swiss cheese' model, and was developed by Dr Scott Shappell and Dr Doug Wiegmann. The framework focuses on the underlying human factors that can lead to accidents $[55,56]$.

The human factors analysis and classification system - maintenance extension (HFACS-ME) is used by the US Navy to classify and categorise maintenance-related factors [51, 54]. The HFACS-ME follows the same structure as the HFACS framework, and is used in a similar way. By using the HFACS-ME in this study, a common vocabulary across industries is established. Table 5 illustrates the HFACS-ME framework together with its underlying factors.

\subsubsection{Results using HFACS-ME framework coding and grouping}

By using the HFACS-ME framework terminology as a guideline, similar human factors were coded. In cases where no similar terminology was found in the HFACS-ME framework, and the human factor was cited a significant number of times, the human factor was added to the HFACS-ME framework. 'High workload' was thus added under 'Inadequate resources'.

$\mathrm{C}^{8}$ Sciences [57] lists the eight core cognitive capacities as sustained attention, response inhibition, speed of information processing, cognitive flexibility and control, multiple simultaneous attention, working memory, category formation, and pattern recognition. Although cognition itself is not listed in the HFACSME framework, its capabilities are listed under 'Attention/memory errors'.

A cumulative percentage of 30 per cent was used to identify the top factors. Table 6 lists the 17 maintenance human factors that were the most often cited using the HFACS-ME framework terminology.

Table 5: The HFACS-ME framework

\begin{tabular}{|c|c|c|}
\hline Level 1 factors & Level 2 factors & Level 3 factors \\
\hline \multirow[t]{2}{*}{ Management conditions } & Organisational & $\begin{array}{c}\text { Inappropriate processes } \\
\text { Inadequate documentation } \\
\text { Inadequate design } \\
\text { Inadequate resources } \\
\text { Communication }\end{array}$ \\
\hline & Supervisory & $\begin{array}{l}\text { Inadequate supervision } \\
\text { Inappropriate operations } \\
\text { Uncorrected problem } \\
\text { Supervisory misconduct }\end{array}$ \\
\hline \multirow{3}{*}{ Maintainer conditions } & Medical & $\begin{array}{c}\text { Adverse mental state } \\
\text { Adverse physical state } \\
\text { Physical/mental limitation }\end{array}$ \\
\hline & Crew coordination & $\begin{array}{c}\text { Inadequate communication } \\
\text { Inadequate assertiveness } \\
\text { Inadequate adaptibility/flexibility } \\
\text { Team work }\end{array}$ \\
\hline & Readiness & $\begin{array}{c}\text { Training/preparation } \\
\text { Certification/qualification } \\
\text { Infringement }\end{array}$ \\
\hline \multirow{3}{*}{ Working conditions } & Environment & $\begin{array}{l}\text { Inadequate lighting/light } \\
\text { Unsafe weather/exposure } \\
\text { Unsafe environmental hazards }\end{array}$ \\
\hline & Equipment & $\begin{array}{c}\text { Damaged/unserviced } \\
\text { Unavailable/inappropriate } \\
\text { Dated/uncertified }\end{array}$ \\
\hline & Workspace & $\begin{array}{l}\text { Confining } \\
\text { Obstructed } \\
\text { Inaccessible }\end{array}$ \\
\hline \multirow{2}{*}{ Maintainer acts } & Error & $\begin{array}{c}\text { Attention/memory } \\
\text { Knowledge/rule-based } \\
\text { Skill/technique-based } \\
\text { Judgement/decision-making }\end{array}$ \\
\hline & Violation & $\begin{array}{l}\text { Routine } \\
\text { Infraction } \\
\text { Exceptional } \\
\text { Flagrant }\end{array}$ \\
\hline
\end{tabular}


Table 6: Top 17 cited human factors using the HFACS-ME framework

\begin{tabular}{|l|l|c|c|c|c|}
\hline $\begin{array}{c}\text { Ran } \\
\mathbf{k}\end{array}$ & \multicolumn{1}{|c|}{$\begin{array}{c}\text { Maintenance human } \\
\text { factor }\end{array}$} & $\begin{array}{c}\text { Frequenc } \\
\mathbf{y}\end{array}$ & $\begin{array}{c}\text { Percentag } \\
\mathbf{e}\end{array}$ & $\begin{array}{c}\text { Cumulative } \\
\text { frequency }\end{array}$ & $\begin{array}{c}\text { Cumulative } \\
\text { percentage }\end{array}$ \\
\hline 1 & Training/preparation & 27 & $3.37 \%$ & 27 & $3.37 \%$ \\
\hline 2 & Skill/technique-based & 21 & $2.62 \%$ & 48 & $5.99 \%$ \\
\hline 3 & Inadequate communication & 18 & $2.25 \%$ & 66 & $8.24 \%$ \\
\hline 4 & Fatigue & 17 & $2.12 \%$ & 93 & $10.36 \%$ \\
\hline 5 & Inadequate lighting/light & 15 & $1.87 \%$ & 111 & $12.23 \%$ \\
\hline 6 & Inadequate design & 13 & $1.62 \%$ & 124 & $15.48 \%$ \\
\hline 7 & High workload & 13 & $1.62 \%$ & 136 & $16.98 \%$ \\
\hline 8 & Judgement/decision- & 12 & $1.50 \%$ & 148 & $18.48 \%$ \\
\hline 9 & making & 12 & $1.50 \%$ & 160 & $19.98 \%$ \\
\hline 10 & Life stress & 12 & $1.50 \%$ & 171 & $21.35 \%$ \\
\hline 11 & Inadequate supervision & 11 & $1.37 \%$ & 181 & $22.60 \%$ \\
\hline 12 & Attention/memory & 10 & $1.25 \%$ & 191 & $23.85 \%$ \\
\hline 13 & Certification/qualification & 10 & $1.25 \%$ & 200 & $24.97 \%$ \\
\hline 14 & Cognition & 9 & $1.12 \%$ & 209 & $26.09 \%$ \\
\hline 15 & Environment & 9 & $1.12 \%$ & 227 & $27.22 \%$ \\
\hline 16 & High noise levels & 9 & $1.12 \%$ & $1.12 \%$ & \\
\hline 17 & Safety & 9 & & $28.34 \%$ \\
\hline
\end{tabular}

\subsection{Results summary}

A ranked comparison of the coding (frameworks) used can be seen in Table 7.

Table 7: Ranked comparison of most often cited maintenance human factors

\begin{tabular}{|l|c|c|c|}
\hline Maintenance human factor & Minimal coding & PEAR model & HFACS-ME framework \\
\hline Workload & 4 & 8 & 7 \\
\hline Time pressure & 8 & 9 & 24 \\
\hline Fatigue & 1 & 6 & 4 \\
\hline Communication & 3 & 1 & 3 \\
\hline Equipment, tools, and parts & 22 & 2 & 22 \\
\hline Cognitive capabilities & 5 & 16 & 14 \\
\hline Supervision & 12 & 10 & 11 \\
\hline Inadequate lighting/light & 2 & 11 & 5 \\
\hline Life stress & 20 & 14 & 10 \\
\hline Judgement/decision-making & 6 & 26 & 8 \\
\hline Noise level & 7 & 17 & 16 \\
\hline
\end{tabular}

The IBM SPSS ${ }^{\circledR}$ software platform was used to perform Spearman's ranked order nonparametric correlation test. This was done to determine whether there was a correlation between the different coding/frameworks used. The output from SPSS can be seen in Table 8.

Table 8: Spearman's ranked order nonparametric correlation test

\begin{tabular}{|c|c|c|c|c|c|}
\hline & \multirow{2}{*}{$\frac{\text { MIN coding }}{1.000}$} & \multirow{2}{*}{$\begin{array}{l}\text { PEAR } \\
0.155\end{array}$} & \multirow{2}{*}{$\begin{array}{r}\text { HFACS-ME } \\
.773^{* \pi} \\
\end{array}$} \\
\hline \multirow[t]{9}{*}{ Spearman’s rho } & \multirow[t]{3}{*}{ MIN coding } & Correlation coefficient & & & \\
\hline & & Sig. (2-tailed) & & 0.650 & 0.005 \\
\hline & & $\mathrm{N}$ & 11 & 11 & 11 \\
\hline & \multirow[t]{3}{*}{ PEAR } & Correlation coefficient & 0.155 & 1.000 & 0.273 \\
\hline & & Sig. (2-tailed) & 0.650 & & 0.417 \\
\hline & & $\mathrm{N}$ & 11 & 11 & 11 \\
\hline & \multirow[t]{3}{*}{ HFACS } & Correlation coefficient & $.773^{* *}$ & 0.273 & 1.000 \\
\hline & & Sig. (2-tailed) & 0.005 & 0.417 & \\
\hline & & $\mathrm{N}$ & 11 & 11 & 11 \\
\hline
\end{tabular}

*. Correlation is significant at the 0.05 level (2-tailed).

**. Correlation is significant at the 0.01 level (2-tailed).

Table 8 shows a significant correlation between the maintenance human factors cited in the literature with minimum coding and the HFACS-ME framework. It is therefore reasonable to use the most listed maintenance human factor from the HFACS-ME framework as the most often cited maintenance human factors in the literature. 
The aim of maintenance measurement frameworks is to manage the maintenance function's performance by tracking the important maintenance elements. Visser and Pretorius [58] developed a total maintenance performance (TMP) scoring system to evaluate a number of performance indicators with weight factors. Galar et al. [59] take a downward hierarchical approach to measurement frameworks. This assists middle management to have directed measurements free of ambiguities. Peach et al. [6] published a table of maintenance performance measurements, including maintenance human factors. By combining Visser and Pretorius [58] and Peach et al. [6], together with the hierarchy approach of Galar et al. [59], the framework depicted in Figure 3 is proposed.

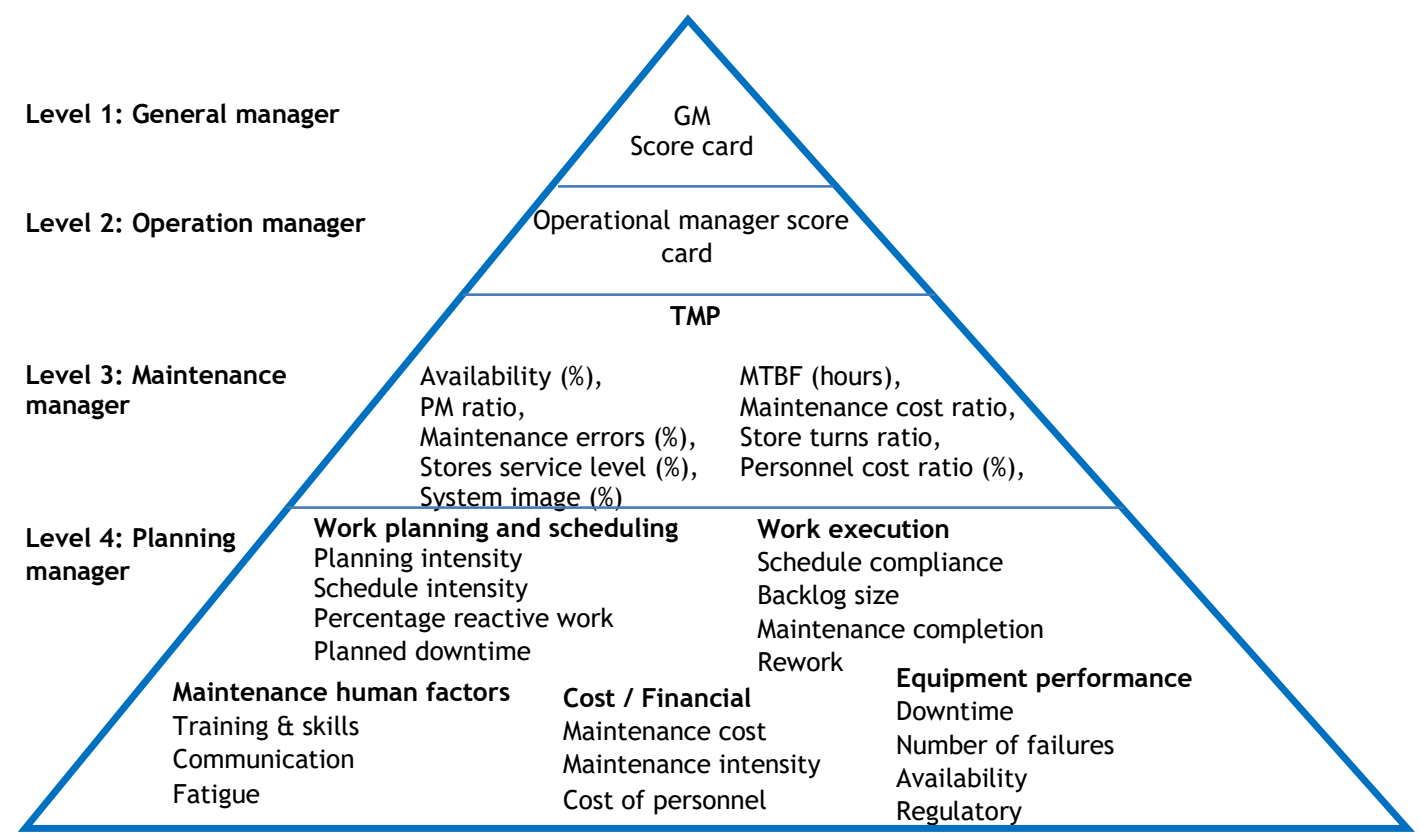

Figure 3: Hierarchical display of the proposed maintenance measurement system

The final Level 4: Maintenance human factors, as illustrated in Figure 3, were chosen from the most often cited HFACS-ME maintenance human factors. It needs to be stressed that a maintenance measurement system should focus on the maintenance human factors that are specific to an industry, rather than on generic factors [1, 60]. By using the most often cited HFACS-ME maintenance human factors, historical organisational data and internal surveys from maintenance staff, the significant maintenance human factors in a specific organisation can be determined. This will ensure that maintenance human efforts will achieve the maximum return on investment.

\section{CONCLUSION}

This article summarises the maintenance human factor measurements that can be used in a maintenance measurement framework. A systematic literature review determined the most often cited maintenance human factors in the literature. It was shown that there is a statistically significant correlation between the most often cited human factors in the literature and those in the HFACH-ME framework. The most often cited HFACH-ME maintenance human factors were training/preparation, skill/technique, inadequate communication, and fatigue.

A hierarchal maintenance measurement framework that includes the most often cited human factors was provided. This framework, together with the listed measurement methods from Table 1, can be used to calculate the TMP for level 4 of the hierarchal maintenance measurement framework.

\section{REFERENCES}

[1] Antonovsky, A., Pollock, C. \& Straker, L. 2014. Identification of the human factors contributing to maintenance failures in a petroleum operation. Human Factors, 56(2), pp. 306-321. 
[2] Reynolds, R., Blickensderfer, E., Martin, A., Rossignon, K. \& Maleski, V. 2010. Human factors training in aviation maintenance: Impact on incident rates. Proceedings of the Human Factors and Ergonomics Society Annual Meeting, 54(19), pp. 1518-1520.

[3] Ljungberg, Õ. 1998. Measurement of overall equipment effectiveness as a basis for TPM activities. International Journal of Operations \& Production Management, 18(5), pp. 495-507.

[4] Simões, J.M., Gomes, C.F. \& Yasin, M.M. 2011. A literature review of maintenance performance measurement: A conceptual framework and directions for future research. Journal of Quality in Maintenance Engineering, 17(2), pp. 116-137.

[5] Peach, R. 2014. A maintenance performance measurement framework inclusive of maintenance human factors for the electricity transmission industry. Master of Engineering (MEM), Graduate School of Technology Management, University of Pretoria.

[6] Peach, R., Ellis, H. \& Visser, J.K. 2016. A maintenance performance measurement framework that includes maintenance human factors: A case study from the electricity transmission industry. South African Journal of Industrial Engineering, 27(2), pp. 177-189.

[7] Muchiri, P., Pintelon, L., Gelders, L. \& Martin, H. 2011. Development of maintenance function performance measurement framework and indicators. International Journal of Production Economics, 131(1), pp. 295-302.

[8] Shepherd, W.T. \& Johnson, W.B. 1995. Human factors in aviation maintenance and inspection: Research responding to safety demands of industry. Proceedings of the Human Factors and Ergonomics Society Annual Meeting, 39(1), pp. 61-65.

[9] Meister, D. 2001. Basic premises and principles of human factors measurement. Theoretical Issues in Ergonomics Science, 2(1), pp. 1-22.

[10] Sheikhalishahi, M., Pintelon, L. \& Azadeh, A. 2017. An integrated approach for maintenance planning by considering human factors: Application to a petrochemical plant. Process Safety and Environmental Protection, 109, pp. 400-409.

[11] Sheikhalishahi, M., Pintelon, L. \& Azadeh, A. 2016. Human factors in maintenance: A review. Journal of Quality in Maintenance Engineering, 22(3), pp. 218-237.

[12] De Winter, J.C. 2014. Controversy in human factors constructs and the explosive use of the NASA-TLX: A measurement perspective. Cognition, Technology \& Work, 16(3), pp. 289-297.

[13] Kantowitz, B.H. 1992. Selecting measures for human factors research. Human Factors, 34(4), pp. $387-398$.

[14] Ziebell, D., John Wreathall \& Company, Electric Power Research Institute, \& Galaxy Scientific Corporation. 2000. Guidelines for trial use of leading indicators of human performance: The human performance assistance package. Washington: Electric Power Research Institute.

[15] Wang, L., Sun, R. \& Yang, Z. 2009. Analysis and evaluation of human factors in aviation maintenance based on fuzzy and AHP method. In IEEE International Conference on Industrial Engineering and Engineering Management, IEEM 2009, pp. 876-880.

[16] Galar, D., Stenström, C., Parida, A., Kumar, R. \& Berges, L. 2011. Human factor in maintenance performance measurement. In 2011 IEEE $18^{\text {th }}$ International Conference on Industrial Engineering and Engineering Management, September 3-5, 2011, Changchun, China, pp. 1569-1576.

[17] Roberts, K.H. \& O’Reilly, C.A. 1974. Measuring organizational communication. Journal of Applied Psychology, 59(3), pp. 321-326.

[18] Downs, C.W. \& Hazen, M.D. 1977. A factor analytic study of communication satisfaction. The Journal of Business Communication (1973), 14(3), pp. 63-73.

[19] Clampitt, P.G. \& Downs, C.W. 1993. Employee perceptions of the relationship between communication and productivity: A field study. The Journal of Business Communication (1973), 30(1), pp. 5-28.

[20] Meintjes, C. \& Steyn, B. 2006. A critical evaluation of the Downs-Hazen instrument (CSQ) by measuring employee communication satisfaction at a private higher education institution in South Africa. Communicatio, 32(1), pp. 152-188.

[21] Chalder, T., Berelowitz, G., Pawlikowska, T., Watts, L., Wessely, S., Wright, D. \& Wallace, E. 1993. Development of a fatigue scale. Journal of Psychosomatic Research, 37(2), pp. 147-153.

[22] Smets, E., Garssen, B., Bonke, B. \& De Haes, J. 1995. The multidimensional fatigue inventory (MFI) psychometric qualities of an instrument to assess fatigue. Journal of Psychosomatic Research, 39(3), pp. 315-325.

[23] Horemans, H.L., Nollet, F., Beelen, A. \& Lankhorst, G.J. 2004. A comparison of 4 questionnaires to measure fatigue in postpoliomyelitis syndrome. Archives of Physical Medicine and Rehabilitation, 85(3), pp. 392-398.

[24] De Waard, D. 1996. The measurement of drivers' mental workload. Doctoral thesis, Groningen University, Netherlands.

[25] O’Donnell, R.D. \& Eggemeier, F.T. 1986. Workload assessment methodology. In K. R. Boff, L. Kaufman, \& J.P. Thomas (eds), Handbook of perception and human performance, Vol. 2. Cognitive processes and performance (p. 1-49). Hoboken: John Wiley \& Sons.

[26] Hwang, S.-L., Yau, Y.-J., Lin, Y.-T., Chen, J.-H., Huang, T.-H., Yenn, T.-C. \& Hsu, C.-C. 2008. Predicting work performance in nuclear power plants. Safety Science, 46(7), pp. 1115-1124.

[27] Guhe, M., Gray, W.D., Schoelles, M.J., Liao, W., Zhu, Z. \& Ji, Q. 2005. Non-intrusive measurement of workload in real-time. Proceedings of the Human Factors and Ergonomics Society Annual Meeting, 49(12), pp. 1157-1161.

[28] Schulz, P., Kirschbaum, C., Prüßner, J. \& Hellhammer, D. 1998. Increased free cortisol secretion after awakening in chronically stressed individuals due to work overload. Stress and Health, 14(2), pp. 91-97.

[29] Institute of Nuclear Power Operations. 2006. Human performance reference manual, INPO 06-003. Atlanta: INPO.

[30] Cohen, S., Kamarck, T. \& Mermelstein, R. 1983. A global measure of perceived stress. Journal of Health and Social Behavior, 24(4), pp. 385-396. 
[31] Levenstein, S., Prantera, C., Varvo, V., Scribano, M.L., Berto, E., Luzi, C. \& Andreoli, A. 1993. Development of the perceived stress questionnaire: A new tool for psychosomatic research. Journal of Psychosomatic Research, 37(1), pp. 19-32.

[32] Kristensen, T.S., Hannerz, H., Høgh, A. \& Borg, V. 2005. The Copenhagen psychosocial questionnaire: A tool for the assessment and improvement of the psychosocial work environment. Scandinavian Journal of Work, Environment \& Health, 31(6), pp 438-449.

[33] MedicineNet. 2018. Medical Definition of Cortisol. Available at: [Accessed 2018-05-22] https://www.medicinenet.com/script/main/art.asp?articlekey=2850.

[34] Banbury, S.P. \& Berry, D.C. 2005. Office noise and employee concentration: Identifying causes of disruption and potential improvements. Ergonomics, 48(1), pp. 25-37.

[35] Burns, P.C., Trbovich, P.L., McCurdie, T. \& Harbluk, J.L. 2005. Measuring distraction: Task duration and the lane-change test (LCT). Proceedings of the Human Factors and Ergonomics Society Annual Meeting, 49(22), pp. 1980-1983.

[36] Healey, A., Sevdalis, N. \& Vincent, C. 2006. Measuring intra-operative interference from distraction and interruption observed in the operating theatre. Ergonomics, 49(5-6), pp. 589-604.

[37] Jett, Q.R. \& George, J.M. 2003. Work interrupted: A closer look at the role of interruptions in organizational life. Academy of Management Review, 28(3), pp. 494-507.

[38] Latorella, K.A. 1996. Investigating interruptions: An example from the flightdeck. Proceedings of the Human Factors and Ergonomics Society Annual Meeting, 40(4), pp. 249-253.

[39] Loukopoulos, L.D., Dismukes, R. \& Barshi, I. 2001. Cockpit interruptions and distractions: A line observation study. Proceedings of the 11th International Symposium on Aviation Psychology, pp. 1-6. Columbus, OH: Ohio State University Press.

[40] Kjellberg, A., Landström, U., Tesarz, M., Söderberg, L. \& Akerlund, E. 1996. The effects of nonphysical noise characteristics, ongoing task and noise sensitivity on annoyance and distraction due to noise at work. Journal of Environmental Psychology, 16(2), pp. 123-136.

[41] Kim, S.-Y., Kim, M.-S. \& Chun, M.M. 2005. Concurrent working memory load can reduce distraction. Proceedings of the National Academy of Sciences, 102(45), pp. 16524-16529.

[42] Valentine, M.A., Nembhard, I.M. \& Edmondson, A.C. 2015. Measuring teamwork in health care settings: A review of survey instruments. Medical Care, 53(4), pp. e16-e30.

[43] Ruiz Ulloa, B.C. \& Adams, S.G. 2004. Attitude toward teamwork and effective teaming. Team Performance Management: An International Journal, 10(7/8), pp. 145-151.

[44] Hellhammer, D.H., Wüst, S. \& Kudielka, B.M. 2009. Salivary cortisol as a biomarker in stress research. Psychoneuroendocrinology, 34(2), pp. 163-171.

[45] Langan-Fox, J., Sankey, M.J. \& Canty, J.M. 2009. Human factors measurement for future air traffic control systems. Human Factors, 51(5), pp. 595-637.

[46] Adams, S.G., Vena, L.C.S. \& Ruiz-Ulloa, B.C. 2002. A pilot study of the performance of student teams in engineering education. American Society for Engineering Education Annual Conference \& Exposition, 2002, vol. 7, pp. 7.83.1-7.83.13.

[47] Flin, R., Martin, L., Goeters, K.-M., Hörmann, H.-J., Amalberti, R., Valot, C. \& Nijhuis, H. 2003. Development of the NOTECHS (non-technical skills) system for assessing pilots' CRM skills. Human Factors and Aerospace Safety, 3(2), pp. 97-119.

[48] Somervell, J., Srinivasan, R., Woods, K. and Vasniak, 0. 2001. Measuring distraction and awareness caused by graphical and textual displays in the periphery. In Proceedings of the 39th Annual ACM Southeast Conference, Blacksberg, VA, 2001.

[49] Wikipedia. 2019. WorldCat. Available [Accessed 24 May 2019]: https://en.wikipedia.org/wiki/WorldCat.

[50] Liberati, A., Altman, D.G., Tetzlaff, J., Mulrow, C., Gøtzsche, P.C., loannidis, J.P., Clarke, M., Devereaux, P.J., Kleijnen, J. \& Moher, D. 2009. The PRISMA statement for reporting systematic reviews and meta-analyses of studies that evaluate health care interventions: Explanation and elaboration. PLoS Medicine, 6(7), p. e1000100.

[51] Krulak, D.C. 2004. Human factors in maintenance: Impact on aircraft mishap frequency and severity. Aviation, Space, and Environmental Medicine, 75(5), pp. 429-432.

[52] CASA. 2013. Safety behaviours: Human factors - Resource guide for engineers. Canberra: Civil Aviation Safety Authority.

[53] Johnson, W.B. \& Maddox, M.E. 2007. A model to explain human factors in aviation maintenance. Avionics News, April, pp. 38-41.

[54] Kang, S. 2017. Application of HFACS (The human factors analysis and classification system) to the Korean domestic passenger ship accidents. Thesis, World Maritime University, Malmö, Sweden.

[55] Reason, J. 1991. Human error. Farnham: Ashgate Books.

[56] Skybrary. 2019. Human factors analysis and classification system (HFACS). Available at [accessed 2019/7/3)] : https://www.skybrary.aero/index.php/Human_Factors_Analysis_and_Classification_System_(HFACS).

[57] $C^{8}$ Sciences. 2018. Cognitive skills: Why the 8 core cognitive capacities. Available: [accessed 2019/7/11] https://www.c8sciences.com/about/8ccc/

[58] Visser, J. \& Pretorius, M.W. 2003. The development of a performance measurement system for maintenance. South African Journal of Industrial Engineering, 14(1), pp. 83-98.

[59] Galar, D., Parida, A., Kumar, U., Stenström, C. \& Berges, L. 2011. Maintenance metrics: A hierarchical model of balanced scorecard. 2011 IEEE International Conference on Quality and Reliability, pp. 67-74.

[60] Tsang, A.H., Jardine, A.K. \& Kolodny, H. 1999. Measuring maintenance performance: A holistic approach. International Journal of Operations \& Production Management, 19(7), pp. 691-715. 